\title{
Phytochemical profile and gastroprotective activity of Eugenia mattosii fruits
}

\author{
Luana dos SANTOS ${ }^{1}$, Adriana CAMPOS ${ }^{2}$, Valdir CECHINEL FILHO² and Luciane Angela Nottar NESELLO²
}

Received 16/8/2017

Accepted 9/1/2018

\begin{abstract}
Background - Extracts obtained from plants and fruits provide a relatively safe and practical alternative for the conventional medicine of gastrointestinal diseases. The specie Eugenia mattosii, popularly known in Brazil as "cerejinha", belongs to Myrtaceae family. Species of this family present pharmacological properties, and can be used in the treatment of gastrointestinal disorders. Objective - The aim of this study was to determine the phytochemical profile and evaluate the gastroprotective activity of Eugenia mattosii fruits. Methods - Phytochemical analysis was carried out by thin layer chromatography and gastroprotective assays were performed using two experimental models: acute ulcer model induced by ethanol/HCl and acute ulcer model induced by non-steroidal anti-inflammatory drug (indomethacin). Total lesion area $\left(\mathrm{mm}^{2}\right)$ and relative lesion area $(\%)$ were determined. Results - The results of the phytochemical analysis indicated that the bark and pulp and seeds of E. mattosii present phenolic compounds, terpenes and/or steroids. In gastric ulcer model induced by ethanol was evidenced significant reduction of damaged areas for doses of $50 \mathrm{and} 250 \mathrm{mg} / \mathrm{kg}$ of seeds methanol extract, while in the indomethacin-induced ulcer model, all parts of the fruit presented defense capability of the gastric mucosa by reducing lesions at doses of 50,125 and $250 \mathrm{mg} / \mathrm{kg}$. Conclusion - The results demonstrate that the specie E. mattosii has bioactive compounds that provide gastroprotective activity, presenting possible therapeutic potential.
\end{abstract}

HEADINGS - Gastrointestinal diseases, therapy. Eugenia. Anti-ulcer agents, pharmacology. Gastric mucosa, drug effects.

\section{INTRODUCTION}

In Southern Brazil, European immigrants influenced the use of native plant $\mathrm{res}^{\mathrm{o}}$ urces. The native resources are strongly associated with local communities, especially concerning the sporadic consumption of fruits and the use of plants for medicinal purposes ${ }^{(1,2)}$.

The discovery of the connection between plants and health is responsible for the beginning of a new generation of therapy that includes drugs derived from plants or their parts. The study of natural products is important to know the real therapeutic potential of these products and their protective activity against inflammatory diseases, as well as gastrointestinal disorders ${ }^{(3)}$.

The consumption of plant foods for maintaining health and preventing chronic diseases increased the interest in bioactive compounds. These components possess different chemical identity and biological activity and provide a relatively safe and practical alternative for the conventional medicine of gastrointestinal diseases $^{(4-6)}$. Among the main factors that lead to the pathogenesis of gastritis and gastric ulcers is the stressful lifestyle, alcohol consumption, use of non-steroidal anti-inflammatory drugs (NSAIDs) and Helicobacter pylori infections ${ }^{(7,8)}$.

The specie Eugenia mattosii, popularly known in Brazil as "cerejinha", belongs to Myrtaceae family. Studies have evidenced gastroprotective activity in some species of this family, such as, Campomanesia reitziana ${ }^{(9)}$, Eugenia punicifolia $^{(10)}$, Eugenia dysenterica $^{(11)}$, Eugenia umbelliflora ${ }^{(12)}$, Myrcianthes pungens and Marlierea tomentosa ${ }^{(13)}$.

There are still no studies on the pharmacological activities of E. mattosii, demonstrating the importance of this research. Ethnopharmacological studies with new species with potential gastroprotective activity are of great importance. These studies will allow a better understanding of the mechanisms of action and safety of medicinal plants, promoting the development of herbal medicines that can be used in the treatment of gastrointestinal disorders $^{(14)}$.

The aim of this study was to determine the phytochemical profile and evaluate the gastroprotective activity of Eugenia mattosii fruits.

\section{METHODS}

\section{Phytochemical analysis}

E. mattosii fruits were collected at Itajaí, Santa Catarina State, Brazil. A voucher specimen was deposited at the Barbosa Rodrigues Herbarium (Itajaí-SC) under number VC Filho 138. Fresh parts (pulp and bark and seeds) of E. mattossi were cut into small pieces and macerated with methanol at room temperature for approximately seven days, providing the methanol extract after solvent evaporation.

Phytochemical analysis was carried out by thin layer chromatography (TLC) with all the extracts to determine the prelim-

Declared conflict of interest of all authors: none

Disclosure of funding: Programa de Bolsas de Pesquisa de Graduação (PROBIC) na Universidade do Vale do Itajaí, Itajaí, SC, Brasil.

${ }^{1}$ Universidade do Vale do Itajaí - UNIVALI, Centro de Ciências da Saúde (CCS), Curso de Nutrição, Itajaí, SC, Brasil. ${ }^{2}$ Universidade do Vale do Itajaí - UNIVALI, Grupo de Pesquisa em Produtos Naturais Bioativos e Núcleo de Investigações Químico-Farmacêuticas (NIQFAR), Itajaí, SC, Brasil.

Corresponding author: Luciane Angela Nottar Nesello. E-mail: nesello@univali.br. 
inary chemical composition. Samples were eluted with different solvent systems with increasingly polarity (hexane: acetone and chloroform: methanol) and revealed with specific reagents such as sulfuric anisaldehyde to terpenes and steroids; ferric chloride to phenolic compounds; potassium hydroxide to coumarins and Dragendorff's reagent to alkaloids ${ }^{(15)}$.

\section{Evaluation of gastroprotective activity}

Female Swiss mice (20-35 g) were provided by the Central Animal House of the Universidade do Vale do Itajaí (UNIVALI) (Itajaí, SC, Brazil). The animals were housed in standard cages, at room temperature $\left(22 \pm 2^{\circ} \mathrm{C}\right)$ with $12 \mathrm{~h}$ dark/12 h light cycles, and received food and water ad libitum. Twelve hours prior to the experiments, they were transferred to the laboratory and given only water ad libitum. In all the experiments, the animals were kept in cages with wide-mesh raised floors to prevent coprophagy. The animals used in the present study were housed and cared for in accordance with the Federal Government legislation on animal care. Also, the experiments were authorized by the Ethical Committee for Animal Care of the Universidade do Vale do Itajai (process number 039/13).

\section{Ethanol/ $/ \mathrm{HCl}$-induced ulcer}

The experiment was performed according to the method described by Mizui and Doteuchi (1983) ${ }^{(16)}$, with some modifications. After $12 \mathrm{~h}$ of fasting, the animals were randomly divided into different groups of six animals each and pre-treated orally with cimetidine (positive control - $100 \mathrm{mg} / \mathrm{kg}$ ), vehicle (negative control - distilled water) and the methanol extracts from bark and pulp and seeds of fruits at doses of 50,125 , and $250 \mathrm{mg} / \mathrm{kg}$. All treatments were administered by gavage.

One hour after treatment, all animals received $0.1 \mathrm{~mL} / 10 \mathrm{~g}$ (body weight) of a $0.3 \mathrm{~mol} / \mathrm{L} \mathrm{HCl} / 60 \%$ ethanol solution (ethanol/ $\mathrm{HCl}$ ) to induce gastric ulcer. Another hour later, the animals were sacrificed by cervical dislocation, and the stomachs removed and opened along the greater curvature. The stomachs were gently rinsed with water to remove the gastric contents and blood clots, for subsequent scanning. The images obtained were analyzed using specific "EARP" software to measure each lesion point. The results were expressed as total lesion area $\left(\mathrm{mm}^{2}\right)$ and relative lesion area $(\%)$.

\section{Non-steroidal anti-inflammatory drug-induced ulcer}

Experiments were carried out according to Rainsford (1980)(17) with a few modifications. After $12 \mathrm{~h}$ of fasting, the animals were randomly divided into different groups of six animals each and pre-treated orally with cimetidine (positive control - $100 \mathrm{mg} / \mathrm{kg}$ ), vehicle (negative control - distilled water) and the methanol extracts from each part of the fruits, at doses of 50,125 and $250 \mathrm{mg} / \mathrm{kg}$. All treatments were administered orally.

One hour after treatment, all the mice received indomethacin $(100 \mathrm{mg} / \mathrm{kg})$ to induce gastric ulcer. Twelve hours after treatment with indomethacin, the animals were sacrificed by cervical dislocation, and the stomachs removed and opened along the greater curvature. The images were scanned and analyzed using image analysis software EARP to determine the number and size of the lesions. The results are expressed as total lesion area $\left(\mathrm{mm}^{2}\right)$ and relative lesion area $(\%)$.

\section{Statistical analysis}

The data are reported as mean \pm standard error of the mean
(SEM) and were compared using one-way analysis of variance (ANOVA), followed by Dunnett's pairwise test, and $P$ values $<0.05$ were considered significant. The GraphPad INSTAT software was used for statistical analysis.

\section{RESULTS AND DISCUSSION}

\section{Phytochemical analysis}

The phytochemical analysis assessed by TLC indicated that bark and pulp and seeds of $E$. mattosii fruits present phenolic compounds and terpenes and/or steroids, however the methanol extract of seeds showed better chromatographic profile. Alkaloids and coumarins were absent in both extracts evaluated (TABLE 1).

TABLE 1. Preliminary phytochemical profile of the studied extracts obtained from E. mattosii.

\begin{tabular}{|c|c|c|c|c|}
\hline $\begin{array}{l}\text { Methanol } \\
\text { extract }\end{array}$ & $\begin{array}{c}\text { Sulfuric } \\
\text { Anisaldehyde }\end{array}$ & $\begin{array}{c}\text { Ferric } \\
\text { Chloride }\end{array}$ & $\begin{array}{l}\text { Potassium } \\
\text { Hydroxide }\end{array}$ & $\begin{array}{l}\text { Dragen- } \\
\text { dorff }\end{array}$ \\
\hline $\begin{array}{l}\text { E. mattosii- } \\
\text { bark and pulp }\end{array}$ & $(+)$ & $(++)$ & $(-)$ & $(-)$ \\
\hline $\begin{array}{l}\text { E. mattosii- } \\
\text { seeds }\end{array}$ & $(++)$ & $(++)$ & $(-)$ & $(-)$ \\
\hline
\end{tabular}

- Absence or traces; + weak; ++ medium; +++ strong.

The genus Eugenia is of interest due to the medicinal properties, attributed to the presence of terpenes and phenolics compounds. These are known to present anti-inflammatory, antioxidant, anti-bacterial and analgesic activity ${ }^{(10,18,19)}$. Terpenes have potential for use in peptic ulcer disease and its activity can be attributed to different mechanisms such as free radical scavenging, inhibition of acid secretion and reinforcing the gastric mucosal barrier ${ }^{(20)}$.

E. uniflora presented phenolic compounds, such as quercetin, quercitrin, isoquercitrin and cyanidin that contribute differentially to the an tioxidant activity ${ }^{(21)}$. E. brasiliensis fruits are indicated for the treatment of gastritis and gastric ulcer. In a recent study, the result showed the presence of phenolic compounds such as flavonoids and ellagitannins in purple and yellow varieties. Anthocyanins and flavonoids (quercetin and cyanidin) were found in the pulp of both varieties of E. brasiliensis, while ellagitannins were present in the bark and seeds ${ }^{(22)}$.

\section{Gastroprotective activity}

Several acute and chronic ulcerative lesions frequently arise anywhere in the gastric mucosa when is exposed to the aggressive action of gastric acid, characterizing the peptic and/or duodenal ulcers, which has implicated the involvement of various mediators. To discover medicinal plants with gastroprotective potential, various animal models have been developed ${ }^{(14)}$.

The ethanol model increases reactive oxygen species ROS, producing necrotic lesions in the gastric mucosa, and the presence of $\mathrm{HCl}$ accelerates this process ${ }^{(16)}$.

The antioxidant activity of phenolic compounds help protect the body from the deleterious effects caused by ROS. Prado and co-workers (2014) ${ }^{(11)}$ observed that E. dysenterica leaves, rich in tannins, possess gastroprotective activity, inhibiting the production of $\mathrm{HCl}$ and presenting antioxidant activity. 
In this study, different doses of the methanol extracts of different parts of E. mattosii fruits were evaluated experimentally for gastroprotective activity. It was evidenced reduction in injured areas at doses of 50 and $250 \mathrm{mg} / \mathrm{kg}$ of seeds, when compared with the control group in ethanol/HCl-induced ulcer model (TABLE 2). These doses decreased the total area of lesion in $69 \%(250 \mathrm{mg} / \mathrm{kg})$ and $66 \%(50 \mathrm{mg} / \mathrm{kg})$ in comparison with the control group, similar to the reduction caused by cimetidine $(73 \%)$.

TABLE 2. Effect of oral administration of $E$. mattosii extracts or cimetidine on ethanol/HCl-induced gastric ulcers in mice $(n=6)$.

\begin{tabular}{lccc}
\hline Treatments & $\begin{array}{c}\text { Dose } \\
(\mathrm{mg} / \mathrm{kg})\end{array}$ & $\begin{array}{c}\text { Total area of } \\
\text { lesion }\left(\mathrm{mm}^{2}\right)\end{array}$ & $\begin{array}{c}\text { Relative area } \\
\text { of lesion }(\%)\end{array}$ \\
\hline Control & - & $57.83 \pm 15.01$ & $14.91 \pm 3.78$ \\
& 50 & $37.85 \pm 4.02$ & $11.14 \pm 1.11$ \\
$\begin{array}{l}\text { E. mattosii - bark } \\
\text { and pulp }\end{array}$ & 125 & $33.06 \pm 6.54$ & $11.29 \pm 2.44$ \\
& 250 & $30.15 \pm 4.52$ & $9.39 \pm 1.36$ \\
& 50 & $19.78 \pm 5.11 *$ & $6.02 \pm 1.52 *$ \\
E. mattosii - seeds & 125 & $38.33 \pm 5.68$ & $12.25 \pm 1.42$ \\
& 250 & $17.86 \pm 5.23 *$ & $6.04 \pm 1.77 *$ \\
Cimetidine & 100 & $15.65 \pm 5.81 *$ & $3.38 \pm 1.19 *$ \\
\hline
\end{tabular}

Results as mean \pm SEM for six rats or mice. Statistical comparison was performed using ANOVA followed by Dunnett's. * $P<0.05$ compared with the control group.

In the indomethacin induced ulcer model, the bark and pulp and the seeds of E. mattossi presented defense capabilities of the gastric mucosa, reducing the injured area at all evaluated doses (TABLE 3). The treatments, especially with E. mattossi bark and pulp at the dose of $125 \mathrm{mg} / \mathrm{kg}$, presented more significant gastroprotective potential than the drug cimetidine, used as a positive control.

The gastroprotective activity caused by NSAIDs exert serious side effects such as bleeding, acute lesions, gastric ulcers, difficulty in healing of gastric ulcers ${ }^{(23)}$ and toxicity ${ }^{(24)}$. The search for more effective and safe treatments is of extreme importance, especially those derived from natural products, demonstrating the relevance of the present study.

A recent study with $M$. pungens (leaves and seeds) and $M$. tomentosa (peel and seeds) (Myrtaceae family) extracts, using the same models of the present study, verified that all treatments, at the dose of $250 \mathrm{mg} / \mathrm{kg}$, exhibited gastroprotective activity when compared to the negative control group (distilled water) ${ }^{(13)}$.
The hydroalcoholic extract from E. punicifolia leaves (125, 250 and $500 \mathrm{mg} / \mathrm{kg}$ ) also demonstrated gastroprotective potential, protecting the rats with acute gastric lesions induced by ethanol or indomethacin. The extract increased the mucus levels of the gastric mucosa without producing an antisecretory effect ${ }^{(10)}$.

\section{CONCLUSION}

In conclusion, the methanol extracts of $E$. mattosii bark and pulp and seeds showed significant reduction in injured areas showing the gastroprotective activity against ethanol and indomethacin.

The preliminary phytochemical analysis demonstrated the presence of phenolic compounds, terpenes and/or steroids in all parts of fruits, but the seeds showed better chromatographic profile. These compounds seem to play a key role in maintaining mucosal integrity. Is necessary more studies in order to identify the principal bioactive compounds, to verify the antioxidant activity and explore the biological mechanisms involved in the gastroprotective action of $E$. mattosii fruits, as well as its therapeutic application in clinical practice.

\section{Authors' contribution}

All authors contributed in the experimental part and writing of this study.

TABLE 3. Effect of oral administration of $E$. mattosii extracts or cimetidine in acute ulcer induced by NSAIDs (indomethacin) in mice $(\mathrm{n}=6)$.

\begin{tabular}{lccc}
\hline Treatments & $\begin{array}{c}\text { Dose } \\
(\mathrm{mg} / \mathrm{kg})\end{array}$ & $\begin{array}{c}\text { Total area of } \\
\text { lesion }\left(\mathrm{mm}^{2}\right)\end{array}$ & $\begin{array}{c}\text { Relative area of } \\
\text { lesion }(\%)\end{array}$ \\
\hline Control & - & $9.54 \pm 3.62$ & $3.86 \pm 1.48$ \\
& & $1.38 \pm 0.36 *$ & $0.51 \pm 0.13 *$ \\
$\begin{array}{l}\text { E. mattosii - } \\
\text { bark and pulp }\end{array}$ & 50 & $1.18 \pm 0.38 *$ & $0.37 \pm 0.11 *$ \\
& 250 & $2.09 \pm 0.34 *$ & $0.66 \pm 0.10 *$ \\
& & & \\
E. mattosii - & 50 & $2.34 \pm 0.48 *$ & $0.74 \pm 0.15 *$ \\
seeds & 125 & $3.39 \pm 1.18 *$ & $0.98 \pm 0.33 *$ \\
& 250 & $2.96 \pm 0.59 *$ & $0.81 \pm 0.15 *$ \\
Cimetidine & 100 & $6.07 \pm 1.25$ & $2.05 \pm 0.37$ \\
\hline
\end{tabular}

Results as mean \pm SEM for six rats or mice. Statistical comparison was performed using ANOVA followed by Dunnett's. $* P<0.05$ compared with the control group. NSAIDs: non-steroidal anti-inflammatory drugs.

Santos L, Campos A, Cechinel Filho V, Nesello LAN. Perfil fitoquímico e atividade gastroprotetora dos frutos de Eugenia mattosii. Arq Gastroenterol. 2018;55(2):138-41

RESUMO - Contexto - Extratos obtidos de plantas e frutos fornecem uma alternativa relativamente segura e prática para os remédios convencionais de doenças gastrointestinais. A espécie Eugenia mattosii, popularmente conhecida no Brasil como "cerejinha”, pertence à família Myrtaceae. Espécies desta família apresentam propriedades farmacológicas e podem ser utilizadas no tratamento de distúrbios gastrointestinais. Objetivo - O objetivo deste estudo foi determinar o perfil fitoquímico e avaliar a atividade gastroprotetora dos frutos de Eugenia mattosii. Métodos - A análise fitoquímica foi realizada por cromatografia em camada delgada e dois modelos experimentais foram utilizados para avaliação da atividade gastroprotetora em camundongos: modelo de úlcera gástrica induzida por anti-inflamatório não-esteroidal (indometacina) e modelo de úlcera gástrica induzida por etanol/ $\mathrm{HCl}$. Resultados - Os resultados da análise fitoquímica indicaram que a casca e polpa e as sementes de E. mattosii apresentam compostos fenólicos, terpenos e/ou esteroides. No modelo de úlcera gástrica induzido pelo etanol, foi evidenciada redução significativa de áreas danificadas para doses de 50 e $250 \mathrm{mg} / \mathrm{kg}$ do extrato das sementes, enquanto no modelo de úlcera induzida por indometacina, todas as partes do fruto apresentaram capacidade de defesa da mucosa gástrica ao reduzir as lesões nas doses de 50,125 e $250 \mathrm{mg} / \mathrm{kg}$. Conclusão - Os resultados demonstram que a espécie E. mattosii possui compostos bioativos com atividade gastroprotetora, apresentando possível potencial terapêutico.

DESCRITORES - Gastroenteropatias, terapia. Eugenia. Antiulcerosos, farmacologia. Mucosa gástrica, efeitos de drogas. 


\section{REFERENCES}

1. Eloy CC, Vieira DM, Lucena CM, Andrade MO. Apropriação e proteção dos conhecimentos tradicionais no Brasil: a conservação da biodiversidade e os direitos das populações tradicionais. Gaia Scientia. 2014;189-98.

2. Rocha FAG, Araújo MFF, Costa NDL, Silva RP. O uso terapêutico da flora na história mundial. HOLOS. 2015;1:49-61.

3. Leite IA, Morais AM, Silva, KD, Carneiro RG, Leite CA. A etnobotânica de plantas medicinais no município de São José de Espinharas, Paraíba, Brasil. Biodiversidade. 2015; $14: 22-30$

4. Baptista IC, Genta TMS, Calderelli VAS, Maurício AA, Portilho M, Matioli G. Conhecimento da comunidade universitária em relação aos alimentos funcionais. Acta Scientiarum. 2013;35:15-21.

5. Dey M, Thomas M. Gastroprotective effects of bioactive foods. In: Watson RR, Preedy VR (Eds). Bioactive food as dietary interventions for liver and gastrointestinal disease. South Dakota: Elsevier; 2013. p. 465-83.

6. Rao V. Phytochemicals - A global perspective of their role in nutrition and health. Rijeka, Croatia: InTech; 2012.

7. Clark ME, Osten AW, Abbas MI, Edwards MJ. Hepatic abscess following NSAID use in an adolescent. J Pediatr Surg Case Rep. 2014;2:33-6.

8. Tandon VR, Khajuria V, Mahajan V, Sharma A, Gillani Z, Mahajan A. Drug-Induced Diseases (Dids): An experience of a tertiary care teaching hospital from India. Indian J Med Res. 2015;142:33-9.

9. Cabral CO, Campos A, da Silva LM, Boeing T, de Andrade SF, Filho VC, Nesello LAN. Gastroprotective potential of methanolic extract and dimethyl cardamonin from Campomanesia reitziana fruits in mice. Naunyn Schmiedebergs Arch Pharmacol. 2017;390:661-6.

10. Basting RT, Nishijima CM, Lopes JA, Santos RC, Périco LL, Laufer S, et al. Antinociceptive, anti-inflammatory and gastroprotective effects of a hydroalcoholic extract from the leaves of Eugenia punicifolia (Kunth) DC. in rodents. J Ethnopharmacol. 2014; 157:257-67.

11. Prado LC, Silva DB, Oliveira-Silva GL, Hiraki KR, Canabrava HA, Bispo-Da-Silva LB. The gastroprotective effects of Eugenia dysenterica (Myrtaceae) leaf extract: the possible role of condensed tannins. Biol Pharm Bull. 2014;37:722-30.

12. Meyre-Silva C, Petry CM, Berté TE, Becker RG, Zanatta F, Delle-Monache F, Cechinel-Filho V, Andrade SF. Phytochemical analyses and gastroprotective effects of Eugenia umbelliflora (Myrtaceae) on experimental gastric ulcers. Nat Prod Commun. 2009;4:911-6.
13. Nesello LAN, Campos A, Rosa RLD, Andrade SF, Cechinel V Filho. Screening of wild fruit trees with gastroprotective activity in different experimental models. Arq Gastroenterol. 2017;54:135-8.

14. Martins JLR, Rodrigues ORL, Sousa FB, Fajemiroye JO, Galdino PM, Florentino IF, et al. Medicinal species with gastroprotective activity found in the Brazilian Cerrado. Fundam Clin Pharmacol. 2015;29:238-51.

15. UGAZ OL. Investigacion fitoquimica, metodos en el estudio de productos naturales. Lima, Peru: Fondo Editorial; 1994.

16. Mizui T, Doteuchi M. Effect of polyamines on acidified ethanol-induced gastric lesion in rats. Jpn J Pharmacol. 1983;33:939-45.

17. Rainsford KD. Biochemical gastroprotection from acute ulceration induced by aspirin and related drugs. Biochem Pharmacol. 1980;29:1281-9.

18. Guzman F, Kulcheski FR, Turchetto-Zolet AC, Margis R. De novo assembly of Eugenia uniflora 1. transcriptome and identification of genes from the terpenoid biosynthesis pathway. Plant Sci. 2014;229:238-46.

19. John KMM, Ayyanar M, Jeeva S, Suresh M, Enkhtaivan G, Kim DH. Metabolic variations, antioxidant potential, and antiviral activity of different extracts of Eugenia singampattiana (an endangered medicinal plant used by Kani Tribals, Tamil Nadu, India) leaf. BioMed Res Int. 2014;2014:1-11.

20. Oliveira FA, Andrade LN, Sousa EBV, Sousa DP. Anti-ulcer activity of essential oil constituents. Molecules. 2014;19:5717-47.

21. Denardin CC, Hirsch GE, Rocha RF, Vizzotto M, Henriques AT, Moreira JCF, et al. Antioxidant capacity and bioactive compounds of four Brazilian native fruits. J Food Drug Anal. 2015;23:387-98.

22. Teixeira LL, Bertoldi FC, Lajolo FM, Hassimotto NM. Identification of ellagitannins and flavonoids from Eugenia brasilienses Lam. (Grumixama) by HPLC-ESI-MS/MS. J Agric Food Chem. 2015;63:5417-27.

23. Kwiecień S, Magierowska K, Śliwowski Z, Wójcik D, Magierowski M, Brzozowski T. New insight into the mechanisms of gastroduodenal injury induced by nonsteroidal anti-inflammatory drugs: practical implications. Pol Arch Med Wewn. 2015;125:191-8.

24. Molina V, Mas R, Carbajal D. D-002 (beeswax alcohols): concurrent joint health benefits and gastroprotection. Indian J Pharm Sci. 2015;77:127-34. 